\title{
Case Study: Mr. Gabriel Marshal Nylowa Yak
}

\author{
James A. Rice
}

\begin{abstract}
In the following case, a refugee and victim of torture, fled religious persecution in Sudan. He first arrived in Syria where he made a claim to asylum to the UNHCR. His claim was initially refused and he fled to Hong Kong. The High Commissioner ruled that Gabriel was an "irregular mover" and that his appeal could not be considered in Hong Kong. He was sent against his will, back to Syria, without any of the documentation that substantiated his claim. During the entire time that his case was being considered, it was closely followed by Amnesty International. Gabriel was ultimately successful in his appeal and was granted protection as a refugee. He was resettled in the United States, where he lives today.
\end{abstract}

\section{Résumé}

Dans le cas qui suit, un réfugié, victime de la torture, s'enfuit de la persécution au Soudan. Il arriva en tout premier lieu en Syrie, où il soumit une demande d'asile à la $H C R$. Sa demande fut rejetédeprime d'abord, et il s'enfuit vers Hong Kong. Le Haut Commissaire jugea que Gabrielétait une " personne aux déplacements irréguliers »et que son appel ne pouvait être entendueà Hong Kong. Contre son gré, il fut renvoyé en Syrie, mais sans aucun des documentsétayant sa demande. Amnesty International avait suivi de près son cas pendant tout le temps que dura l'examen de son appel. Gabriel eut finalement gain de cause et obtint la protection du statut de refugié. Il aété réinstalléaux États Unis, où il vit aujourd'hui.

James Rice is currently an assistant professor at Lingnan University in Hong Kong where he teaches law and philosophy. Mr. Rice is also an associate at the law firm of Pam Baker \& Company where he works on refugee and other issues.

\section{Background}

Gabriel was born in Wau, southern Sudan in 1973. His father was a farmer and his mother was a farmer and housewife. In addition, Gabriel has three siblings, two elder brothers, Edward and Joseph and a sister, Mary. Gabriel is the youngest in the family.

The war between the government forces and the various opposition armed groups dominated a large part of Gabriel's formative years. Gabriel claims that during his own childhood, starvation was widespread across the entire southern region. The problem intensified following the rebellion in 1983 by the Sudan Peoples' Liberation Army (SPLA).

In 1991, Gabriel's father was killed by the military. He had lived in a village called Umbilli located near Wau. The village had been captured by the SPLA, and then retaken by government forces. Government soldiers accused Gabriel's father of involvement in the SPLA and arrested him. In fact, Gabriel's father, (Marshal Nylowa Yak) had only assisted SPLA troops by giving them some sheep and goats. Gabriel was later told by tribal members that his father had been tortured by government troops and then later shot.

In 1992, in an effort to escape the war which was then engulfing the south of the country, the rest of the family moved to a place called El Obeid. Here, Gabriel seems to have attended high school. The school was run by Catholic missionaries and was called Comboni School. Gabriel received his diploma from Comboni in 1994 in accounting, mathematics and business. His ambition was to attend college and study economics.

During his high school years, Gabriel worked part-time as a construction worker, building homes and doing upkeep on houses. He was also involved in Catholic church activities and his youth group would regularly visit homes and pass out literature on Sundays in addition to worship service.

In 1993, the family moved once again, this time to the outskirts of Khartoum. They moved to this place because following the death of his father, there was no one to support the family and renting the house in El Obeid was financially difficult. The move to Khartoum was also done in order to be further away from the civil war. In Khartoum, although the family faced discrimination, according to Gabriel, treatment was better because there they were not threatened by the war. The family also made the move to Khartoum because according to Gabriel, in the suburbs of the city there was space for them to build a shelter. The shelter consisted of two rooms built of mud and wood and an adjoining tent which served as a place for cooking meals.

While in Khartoum, Gabriel went to church and became interested in church activities. In August 1994, Gabriel was found by security officers on the streets together with some of his friends. The were carrying bibles and other religious literature. The officers asked as to what type of books they were carrying. They showed them the bibles and they were arrested and put into vehicles and taken to the Sudan Security Office. Upon being admitted, the group was separated and slapped and punched by officers. Then, other officials asked as to what their activities were. Gabriel told them that they were visiting families and handing out the literature that they had with them.

He was taken to an interrogation room and beaten with sticks on his legs and shins. The beating went on from 
about 10:00 in the morning until the evening. On both his left and right shins there remain scar tissue from these beatings. ${ }^{1}$

In the evening of that day Gabriel and his friends were released from custody. The same happened again in October of 1994, also relating to Gabriel's being arrested for carrying and distributing Christian materials. Once again he was interrogated and beaten by security officers.

By 1995, Gabriel was working part time helping a friend who earned a living by repairing and cleaning computers. Gabriel's task included cleaning the machines. He was able to earn on average $\$ 10.00$ per week doing this. One of the significant events that shaped Gabriel's life also took place in 1995.

On 13 July 1995, in an effort to galvanize the people to further prosecute the war in the south, the Sudanese president, Lt. Gen. Omar Hassan Ahmad al Bashir spoke to students at Khartoum University (KU). He urged them to report formilitary duty and go to the south in order to "liberate" the region. According to Gabriel, this speech seems not at all to have had the effect that was intended by the president. The students already tired of the war and not inclined to volunteer for army duty, came out onto the streets and protested against the ruling National Islamic Front (NIF) and against the war in the south. Gabriel who was on the streets of Khartoum at the time, saw the protest and joined them.

The students initially marched from the KU campus to the bus terminal, in hopes of being seen by many people and of gathering additional supporters. From there, they marched to Government House, where they aired their grievances against the authorities. Gabriel was involved in this initial demonstration in front of Government House. At this point, the police and security forces confronted the demonstrators using tear gas and riot sticks in an effort to disperse the crowd.

The student protests went on for nearly a week, both in Khartoum and in Port Sudan. The student demonstra- tions came at a particularly sensitive time in Sudan, as there had recently been an attempted military coup staged by military officers against the National Islamic Front as well.

In response to the demonstrations, the government took a hard line by cracking down on all forms of popular discontent. Government media accused the protesters of being communists and police and troops were used to break up any assembly of people. According to Gabriel, the police and troops used tear-gas and batons to break up any further public protests.

As the protests went on, the authorities expanded their crack-down on the population in general. Troops were sent out and check points were set up in and around Khartoum. This was done in order to stop and question young men found to be on the roads. If these individuals could produce no evidence that they were currently attending either college or university, they were arrested and conscripted into the army.

Gabriel was caught by the troops and conscripted into the army in this way. On 3 August 1995, he was stopped, searched, and ordered to produce an identity card. As he did not have an identity card, and could not show that he was attending university at the time, Gabriel was taken to an army camp in Jebel Aulia. There, his hair was shaved off and he was given the white uniform of new recruits. After about two weeks of basic training, he escaped the camp and fled to a place called Shajara and from there, back to Khartoum.

At that point, in an effort to avoid any further threat of military service, Gabriel applied to attend a university in Bucharest, Romania. He candidly admitted that his primary desire was to be able to leave Sudan rather than attend university in Romania. Gabriel sent the request for the information and received the application forms. He filled them in and sent them back.

During this time, Gabriel went into hiding at home in his family's shelter on the outskirts of Khartoum.
Gabriel felt very strongly that he could not and would not serve in the Sudanese Army. To do so would have been to go against his conscience. First and foremost, he felt that he couldn't fight in a war against his own people. The people in the south are generally Christians and the war, according to Gabriel, was an attempt by the ruling National Salvation Front to Islamize the south by use of military force.

For Gabriel, this meant that he would not only be fighting in a war that he didn't believe in, but that he would be fighting against members of his own ethnic group, against his own tribe and even more importantly, against other Christians like himself. In addition, Gabriel was still mindful that the Sudanese Army were the ones responsible for murdering his father back in 1991. Most importantly though, Gabriel refused to serve in the Sudanese military because it ran contrary to his religious convictions.

\section{Detention}

On 4 November 1995, Gabriel was once again arrested by troops in a random street search in Khartoum and was taken to the same military camp as before. It was then discovered from the military records that he was a deserter and he was taken to a detention centre in Khartoum, put in detention and beaten and tortured for three days. According to Gabriel, a member of the security forces also identified him at that time as having been involved in the student protests of 13 July.

During this time, Gabriel was held in solitary confinement in an isolated concrete cell and was beaten, kicked and abused by successive teams of soldiers as well as members of the security forces who were dressed in civilian clothes. The cell itself was about 3 meters by 3 meters, with nowindows or other forms of ventilation. The sanitation consisted of a latrine bucket filled with the urine and excrement of the previous inmate. During this time, Gabriel was given dry bread and no water at all. 
During these torture sessions he was repeatedly slapped and beaten in the face and torso. In addition, he was struck repeatedly in the kidneys and genitals by soldiers using rifle butts. During one such session, Gabriel was beaten unconscious by blows to his genitals.

In between the beatings, he was extensively interrogated by plain-clothes officers who asked him for information about other members of his family and his political background. They also wanted information about any possible involvement in the SPLA. During the interrogation, Gabriel confessed that his father had been shot by government troops in the town of Umbilli in 1991.

The response of the security personnel was to assume that Gabriel's father had been somehow involved in the SPLA. This singled him out for additional torture by the plain clothes officers. The officers engaged in the interrogation did not generally administer the beatings or other forms of torture. This was left for the most part to uniformed soldiers. However, on some occasions these officers also engaged in beatings. And on several occasions the plain clothes security officers burned Gabriel's arms and legs with cigarette butts. At one point in the interrogations one of the security officers grabbed the small wooden cross that hung about Gabriel's neck and shouted, "You are a Christian? It is you people who are causing trouble in the country".

He also endured repeated sessions where he was whipped on the back and legs with a lash made of leather and having three "tails". The soldiers also on one occasion used a red hot poker to burn his skin. Gabriel still bears a scar from this incident. The burn scar, which is about four centimeters in diameter, bears witness to someone having sustained third degree burns and is located on his left hip. ${ }^{2}$

During the second day of his detention, a soldier entered Gabriel's cell while Gabriel was seated on the floor. The soldier took out a knife and cut his leg, just above the knee. There remains a scar on the left thigh, indicating a lateral incision of about four centimeters in length and 3 millimeters deep. ${ }^{3}$

On both the first and the third days of the interrogation session, a group of security officers took Gabriel out of his cell to a yard behind the cell block and then returned him to his cell again. The officers prepared a bunch of dried chillies inside the cell and then set fire to them. The resulting smoke and fumes caused extensive irritation to Gabriel's eyes, nose and throat, causing him to cough, gag and vomit. The irritation from the burning chillies lasted for nearly four hours. Even several weeks after his release from detention, Gabriel continued to cough as a result of inhaling the smoke from the chillies.

On each day of detention, he was taken from his cell, made to lie down on the ground and exposed to the sun for two hours. During this time, he was not given water. He was ordered to lie motionless for the entire time. If he moved during this time, he was exposed to fresh kicks from soldiers. At night, he was taken out of the cell and at midnight troops poured cold water over him. During the "cold water showers" Gabriel was able to drink some of the water that was poured on him. This treatment of exposure to both the heat of the day and cold water during the night for three days and nights resulted in extreme discomfort and disorientation. At the end of the three days of torture, Gabriel was released for resumption of basic training at the army camp in Jebel Aulia. Upon his release from detention, Gabriel was threatened by the security officer that if he were ever to escape again, he would be "shown hell".

\section{Flight to Freedom}

During the evenings, the conscripts would be forced to attend Islamic education lectures. During a break in the proceedings, Gabriel pretended to go off to use the toilet and made his escape from the army camp. From Jebel Aulia, he returned to Khartoum and to his family's house. On returning home, Gabriel found a letter of admission from the University of Bucharest. On 9
November, Gabriel went to the Immigration Department and presented the admission letter. He was issued an exit visa from the country on the same day on the 10th and left Sudan, ostensibly bound for Romania.

Although Gabrielhad been accepted by the university in Bucharest, he never had any real intention of going there. His real plan was to flee from Sudan and the letter from the university was a way for him to obtain an exit visa from the immigration authorities.

Gabriel stopped off in Syria on 10 November and there found work on a farm, watering apple and olive trees and weeding the orchards. This was difficult work with very long hours. After being badly treated as an illegal worker, Gabriel got a job in a textile factory. The work involved carrying materials into the plant and finished product out.

In June 1996, Gabriel approached the UNHCR and made a claim for asylum. He was interviewed for fifteen to twenty minutes and was then told to come again in a month's time. The interview was only cursory and he was never asked about his treatment by the Sudanese security officials.

At the time that Gabriel made his original claim to the UNHCR office in Damascus, he was still suffering from the effects of the trauma that he had experienced at the hands of the security officers in Sudan. He had recently undergone torture and a great deal of physical and mental abuse. ForGabriel, the people who had administered the beatings and the abuse had been Moslems who where ethnically Arabic. The man who conducted the UNHCR interview in Damascus had been a man of Arabic origin, with a Moslem name. Gabriel found himself to be in a truly difficult situation. From his point of view, the man conducting the interview was the same, in both ethnicity and religion as those who he had fled from. Gabriel simply wasn't able to make his claim to asylum in a free and candid manner. Gabriel had grown up in a country where there was no concept of freedom of expression or of conscience. During that brief interview, 
Gabriel was unable to make a claim that would be recognizable by the UNHCR.

He came to the office after one month and was told to come back again in another month. Finally after four months, in September 1996, Gabriel received a scrap of paper with just one word written on it, "rejected".

While in Damascus, Gabriel had attended the local Catholic church there. He had spoken to the priest about his difficulties and the church had provided Gabriel with $\$ 900$ ( $\$ 450$ having been raised by the young people in the congregation, and the rest from the priest himself). This money was used to buy a ticket to Hong Kong. Upon his arrival in Hong Kong, Gabriel sought the assistance of the UNHCR and claimed asylum as a refugee.

\section{Grounds for Refugee Status}

Gabriel Marshal Nylowa Yak had a well founded fear of persecution by the authorities in Sudan because of his Christian faith and his insistence to worship and be involved in church activities. He also was under threat of further persecution because of his record of being a conscientious objector to military service as well as his desertion from duty on two occasions. This was evidenced partly by the fact that he was subjected to torture following his initial desertion. When he was arrested on 4 November, and taken to the army base, his records showed that he had previously been conscripted and was then singled out for torture. Gabriel had by his convictions and his actions had demonstrated that he had fled the Sudanese military because he was a conscientious objector.

Paragraphs 167-171 of the UNHCR Handbook $^{4}$ refers to protection of conscientious objectors. Specifically, paragraph 169 states:

$A$ deserter or draft-evader may also be considered a refugee if it can be shown that he would suffer disproportionately severe punishment for the military offence on account of his race, religion, nationality, membership of a particular social group or political opinion. ${ }^{5}$
Further, paragraph 170 indicates:

There are, however, also cases where the necessity to perform military service may be the sole ground for a claim to refugee status, i.e. when a person can show that the performance of military service would have required his participation in military action contrary to his genuine political, religious or moral convictions, or to valid reasons of conscience. ${ }^{6}$

The treatment of Gabriel by the security officials as well as army troops was clearly in violation of internationally accepted standards.

Article 1 of the United Nations Convention Against Torture and Other Cruel, Inhuman or Degrading Punishment defines torture as being:

Any act by which severe pain or suffering, whether physical or mental, is intentionally inflicted on a person for such purposes as obtaining from him or a third person information or a confession, punishing him for an act he or a third person has committed or is suspected of having committed, or intimidating or coercing him or a third person, or for any reason based on discrimination of any kind, when such pain or suffering is inflicted by or at the instigation of or with the consent or acquiescence of a public official or other person acting in an official capacity. $^{7}$

Article 3(1) of the United Nations Convention Against Torture and Other Cruel, Inhuman or Degrading Treatment or Punishment states:

No State Party shall expel, return (refouler) or extradite a person to another State where there substantial grounds for believing that he would be in danger of being subjected to torture. ${ }^{8}$

Article 7 of the International Covenant on Civil and Political Rights, (ICCPR) prohibits the use of torture, cruel or inhuman or degrading treatment or punishment. In addition, Article 10(1) of the same convention states:

..all persons deprived of their liberty shall be treated with humanity and with respect for the inherent dignity of the human person. ${ }^{9}$

Gabriel in his submission to the Hong Kong Office of the UNHCR also referred to authority decided by the United $\mathrm{Na}$ tions Human Rights Committee, namely Estrella $v$ Uruguay ${ }^{10}$ and
Vuolanne $v$ Finland. ${ }^{11}$ Estrella offers authority for the proposition that treatment that Gabriel was subjected to in detention was in breach of Article 7 of the International Covenant on Civil and Political Rights (that no one shall be subjected to cruel, inhuman or degrading treatment or punishment). Voulanne decided that the failure by the Finnish military to provide due process to military personnel under detention is in breach of Article 9 of the ICCPR (no one shall be subjected to arbitrary arrest or detention).

Article 3(2) of the United Nations Convention Against Torture and Other Cruel, Inhuman or Degrading Treatment or Punishment goes on to indicate that:

For the purpose of determining whether there are such grounds, the competent authorities shall take into account all relevant considerations including, where applicable, the existence in the State concerned of a consistent pattern of gross, flagrant or mass violations of human rights. ${ }^{12}$

Gabriel cited evidence that the authorities in Sudan routinely employ detention without charge or trial as well as torture as a means of silencing political opposition. It is also well documented that torture and ill treatment of prisoners are endemic in the Sudanese detention system.

In addition, Gabriel referred to the Amnesty International text on Sudan. ${ }^{13}$ Here Amnesty has documented the systematic use of mistreatment and torture of detainees by members of the security services. This practice referred to as idara dakalia (internal administration) is used by the military on both civilians and on conscripts.

Finally, the World Report, issued by Human Rights Watch and its chapter on Sudan. ${ }^{14}$ In this report, Human Rights Watch points out that Sudanese regime was in April 1996, condemned by the U.N. Commission on Human Rights. The commission cited its "deep concern," for reports of "grave human rights violations in Sudan." Included among the commissions top concerns were, extrajudicial, summery or arbitrary executions. The Human Rights 
Watch report alog independent dout monitor group is all Sudan.

The UNAC The Hong Kong o egorized Gabrit: mover" becaus? claimed asylumit. to hear his subats and insisted (de. would be denied Sudan) that he order to appeal decision. This dit the UNHCR way ful,notonly becau : that Gabrielhad of also because he w. ing the results of tion that was cor corroborating his ing subjected to to decision was UNHCR policy 4 . "irregular movan." asylum, it does r. Gabriel had alno. resentation in $\mathrm{H}^{2}$. sion to send hist? tantamount to $\mathrm{d}^{2}$ process.

Gabriel was fo. and arrived the Although the $U_{\text {s? }}$ Kong claimed. his submission to the Damascus ofitice, Gabriel was informed by staff Swher he went there that the files had been "lost." The appeal submission and the medical report were then rushed direct to Gabriel by courier. $\mathrm{He}$ and an interview in March with a wection officer from the UNHCR and mas ultimately recognized as a refugee in April, 1997. Gabriel's application wes forwarded to the United States Department of Justice, Immigration and Naturalization Service in Athens, Greece, and he was granted refugee statusin May, 1997. Gabriel was resettled in the U.S. later in 1997.

Gabriel's case is certainly not unique. However, it does represent the systematic persecution that people of faith withinSudan havelong been subjected to. His resourcefulness, persistence and luck enabled him to flee from persecution in his country and tell his story to the world. This case is also a good exemple of the problems that exist within the UNHCR and the lack of transparency regarding individual decisions and accountability for those decisions that presently exist within that agency.

\section{NOTES}

1. Medical Report, submitted by Dr. Robert Cocks, Director of A \& EMedicine, Chinese University of Hong Kong, Accident and Emergency Unit, Prince of Wales Hospital, New Territories, Hong Kong. All of the scars and other evidence of injury were found to have been consistent with having been inflicted by torture.

2. Medical Report of Gabriel Marshal Nylowa Yak, p. 2.

3. ibid, pp. 2-3

4. UNHCRHandbook on Procedures and Criteria for Determining Refugee Status, Geneva, (1979), pp. 39-40.

5. UNHCR Handbook, p. 40.

6. ibid.

7. Convention Against Torture and Other Cruel, Inhuman or Degrading Treatment or Punishment, (1984) U.N. Doc. A/RES/ 39/46. Found in Basic Documents on Human Rights, edited by Ian Brownlie, (1997) pp. 38-39.

8. Convention Against Torture and Other Cruel, Inhuman or Degrading Treatment or Punishment, Brownlie, p. 39.

9. ibid, p. 40.

10. H.R.C. 93 (1983). Found in, Cases and Materials on International Law, D.J. Harris, Sweet \& Maxwell, (1991) pp. 630-634.

11. H.R.C. Report, G.O.A.R., $44^{\text {th }}$ Sess., Supp. P. 249 (1988). Found in Cases and Materials on International Law, D.J. Harris, Sweet \& Maxwell (1991) pp. 634-637.

12. United Nations Convention Against Torture and OtherCruel, Inhuman or Degrading Treatment or Punishment. Article3(2) Found in. Basic Documents on Human Rights, Brownlie, (1997) p. 39.

13. Amnesty International, Sudan, Amnesty International (1995) pp. 25-35.

14. Human Rights Watch, World Report, Human Rights Watch, (1997) pp. 55-60. 口

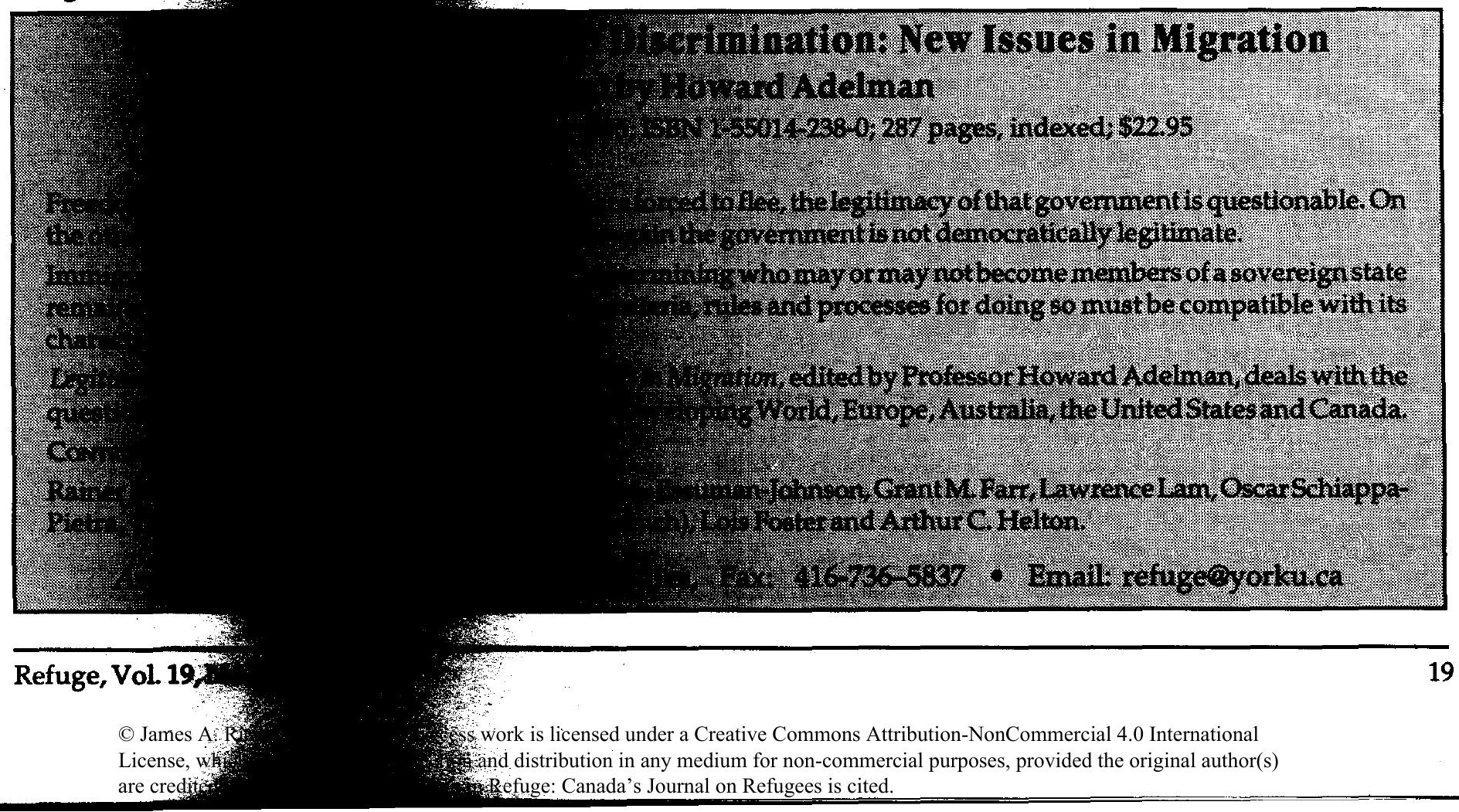

